\title{
Thyroid hormone resistance and increased metabolic rate in the RXR- $\gamma$-deficient mouse
}

\author{
Nicole S. Brown, ${ }^{1}$ Alexandra Smart,${ }^{1}$ Vibha Sharma, ${ }^{1}$ Michelle L. Brinkmeier, ${ }^{2}$ \\ Lauren Greenlee, ${ }^{2}$ Sally A. Camper, ${ }^{2}$ Dalan R. Jensen, ${ }^{1}$ Robert H. Eckel, ${ }^{1}$ \\ Wojciech Krezel, ${ }^{3}$ Pierre Chambon, ${ }^{4}$ and Bryan R. Haugen ${ }^{1}$ \\ ${ }^{1}$ Department of Medicine, University of Colorado Health Sciences Center, Denver, Colorado, USA \\ ${ }^{2}$ Department of Human Genetics, University of Michigan Medical School, Ann Arbor, Michigan, USA \\ ${ }^{3}$ University of Wales, School of Molecular and Medical Biosciences, Physiology Unit, Cardiff, Wales, United Kingdom \\ ${ }^{4}$ Institut de Génétique et de Biologie Moléculaire et Cellulaire, Centre National de la Recherche Scientifique, \\ Institut National de la Santé et de la Recherche Médicale, Universit Louis Pasteur, Collège de France, \\ Communaunte Urbaine de Strasbourg, France
}

Address correspondence to: Bryan R. Haugen, B151, University of Colorado Health Sciences Center, 4200 East 9th Avenue, Denver, Colorado 80262, USA. Phone: (303) 315-8443; Fax: (303) 315-4525; E-mail: bryan.haugen@uchsc.edu.

This work was presented at the 81st Annual Meeting of the Endocrine Society in San Diego,

California, USA, June 12-15, 1999.

Received for publication January 19, 2000, and accepted in revised form May 16, 2000.

\begin{abstract}
Vitamin A and retinoids affect pituitary-thyroid function through suppression of serum thyroidstimulating hormone (TSH) levels and TSH- $\beta$ subunit gene expression. We have previously shown that retinoid $\mathrm{X}$ receptor-selective (RXR-selective) ligands can suppress serum TSH levels in vivo and TSH- $\beta$ promoter activity in vitro. The RXR- $\gamma$ isotype has limited tissue distribution that includes the thyrotrope cells of the anterior pituitary gland. In this study, we have performed a detailed analysis of the pituitary-thyroid function of mice lacking the gene for the RXR- $\gamma$ isotype. These mice had significantly higher serum T4 levels and TSH levels than did wild-type (WT) controls. Treatment of RXR$\gamma$-deficient and WT mice with T3 suppressed serum TSH and T4 levels in both groups, but RXR$\gamma$-deficient mice were relatively resistant to exogenous T3. RXR- $\gamma$-deficient mice had significantly higher metabolic rates than did WT controls, suggesting that these animals have a pattern of central resistance to thyroid hormone. RXR- $\gamma$, which is also expressed in skeletal muscle and the hypothalamus, may have a direct effect on muscle metabolism, regulation of food intake, or thyrotropin-releasing hormone levels in the hypothalamus. In conclusion, the RXR- $\gamma$ isotype appears to contribute to the regulation of serum TSH and T4 levels and to affect peripheral metabolism through regulation of the hypothalamic-pituitary-thyroid axis or through direct effects on skeletal muscle.
\end{abstract}

J. Clin. Invest. 106:73-79 (2000).

\section{Introduction}

Vitamin A and its retinoid derivatives influence the function of the pituitary-thyroid axis $(1,2,3)$. In one study, vitamin A-deficient rats had significantly higher serum T4 and T3 levels than were found in vitamin A-sufficient controls (3). Pituitary thyroid-stimulating hormone (TSH) content was also higher in the vitamin A-deficient rats, suggesting a biochemical pattern of central hyperthyroidism.

A recent study examined the effect of the retinoid $\mathrm{X}$ receptor-selective (RXR-selective) retinoid LG1069 on the pituitary-thyroid axis in 27 patients treated with this retinoid for cutaneous T-cell lymphoma (4). Twenty-six of these patients developed reversible central biochemical hypothyroidism, and 19 of them had clinical symptoms of hypothyroidism, suggesting that these new potent retinoids can influence pituitary-thyroid function at the level of the pituitary.

Our group has shown that 9-cis retinoic acid, a panreceptor agonist that interacts with retinoic acid recep- tor (RAR) and RXR, suppressed TSH- $\beta$ promoter activity by $60 \%$ in thyrotropes (5). We have also shown that the RXR-selective retinoid LG346 also suppressed TSH- $\beta$ promoter activity by $50 \%$ in these same thyrotrope cells (4). These two studies suggest that the negative regulation of TSH- $\beta$ promoter activity, and presumably expression of the gene by retinoids, is mediated primarily through RXR.

During mouse development, RXR- $\alpha$ and RXR- $\beta$ are diffusely expressed (6), whereas the expression of RXR- $\gamma$ is limited to the central nervous system and cells of myogenic lineage. RXR- $\gamma$ appears in the anterior pituitary on day 15.5 after conception, but is not expressed in the pars intermedia or neurohypophysis. Furthermore, RXR- $\gamma$ is diffusely expressed in the thyroid on day 16.5 after conception, suggesting that this transcription factor may play an important role in thyrotrope and thyroid development and function (7). Both RXR- $\alpha$ and RXR- $\beta$ are widely expressed in adults, including in the anterior pitu- 
itary, whereas RXR- $\gamma$ has a very limited tissue distribution that includes skeletal muscle and the pituitary. Furthermore, Sugawara and colleagues (8) showed that RXR- $\gamma$ protein expression is restricted to thyrotropes within the rat anterior pituitary gland. Sanno and colleagues (9) recently demonstrated that RXR- $\gamma$ protein expression was limited to thyrotropes in the human anterior pituitary.

A transgenic mouse gene deletion of RXR- $\gamma$ has been performed, and the mice appeared phenotypically normal (7). Histology of the pituitary and muscle, two organs with restricted expression of RXR- $\gamma$, appeared to be normal. In this study, we have performed a detailed analysis of the pituitary-thyroid axis in the RXR- $\gamma$-deficient mouse model to investigate the role of this receptor on pituitary-thyroid function. We have also begun to investigate the metabolic consequences of this gene defect.

\section{Methods}

Mice. Female $R X R-\gamma^{1-}$ mice (7) were bred with $129 \mathrm{SvJ}$ male mice (The Jackson Laboratory, Bar Harbor, Maine, USA) to generate heterozygotic mice. These were further intercrossed for two generations to generate $R X R-\gamma^{/-}$, $R X R-\gamma^{+-}$, and $R X R-\gamma^{+/+}$littermate mice for analysis. Genotype analysis was performed by PCR of genomic DNA. Tail sections $(5-10 \mathrm{~mm})$ were treated with $0.3 \mathrm{mg}$ of proteinase K (Sigma-Aldrich Co., St. Louis, Missouri, USA) overnight at $55^{\circ} \mathrm{C}$ in $300 \mu \mathrm{L}$ of DNA extraction buffer (50 mM Tris- $\mathrm{HCl}$ at $\mathrm{pH} 8.0,10 \mathrm{mM}$ EDTA, $100 \mathrm{mM}$ $\mathrm{NaCl}$, and $0.1 \% \mathrm{SDS}$ ). One microliter of the extract was subjected to 35 cycles of PCR $\left(95^{\circ} \mathrm{C}\right.$ for 15 seconds, $56^{\circ} \mathrm{C}$ for 15 seconds, and $72^{\circ} \mathrm{C}$ for 15 seconds). Oligonucleotides corresponding to exon 4 of $R X R-\gamma$ (sense: $5^{\prime}$ AACCAGGGAAGCACTACGGT-3', antisense: $5^{\prime}$-ATACCTCACCTTCCCGCTTC-3'; 195 bp) and the neomycin resistance marker cDNA (sense: 5'-GTTCTTTTTGTCAAGACCGACC-3', antisense: 5'-ATACTTTCTCGGCAGGAGCA$3^{\prime} ; 205 \mathrm{bp}$ ) were used. oligonucleotides corresponding to GAPDH (sense: 5'-CCTTCTCCATGGTGGTGAAGAC-3', antisense: 5'-ATGGTGAAGGTCGGTGTGAACG-3'; 316 bp) were used as a positive control. All mice used in these studies were treated in accordance with National Institutes of Health guidelines on animal use and care. Male and female mice were used in all experiments, except for the metabolic rate and growth studies in which only male mice were used.

RT-PCR analysis. RNA was prepared from six pooled pituitaries in each group as described previously (10). One microgram of total RNA was subjected to reverse transcription with random hexamers $(1 \mu \mathrm{g})$ and $30 \mathrm{U}$ of avian myeloblastosis virus reverse transcriptase (Promega Corp., Madison, Wisconsin, USA). The product was divided into six parts for PCR, for RXR$\gamma 1$, TSH- $\beta$, growth hormone (GH), thyroid hormone receptor $\beta 1$ (TR- $\beta 1$ ), TR- $\beta 2$, and GAPDH. PCR reactions were carried out with $500 \mathrm{ng}$ of sense and antisense oligonucleotides generated against unique regions of each target cDNA. Annealing tempera- tures for the reactions were $52.5^{\circ} \mathrm{C}$ (RXR- $\gamma 1$ and $\mathrm{GAPDH}), 58^{\circ} \mathrm{C}(\mathrm{TSH}-\beta), 60^{\circ} \mathrm{C}$ (TR- $\beta 1$ and TR- $\beta 2$ ), and $62^{\circ} \mathrm{C}(\mathrm{GH})$. PCR reactions were performed with 2.5 U Taq polymerase (Roche Molecular Biochemicals, Mannheim, Germany) at $94^{\circ} \mathrm{C}$ for 1 minute, annealing temperature for 1 minute, and $72^{\circ} \mathrm{C}$ for 1 minute over 40 cycles in a total volume of $50 \mu \mathrm{L}$. Ten microliters of the reaction mixture was removed at 30,35 , and 40 cycles; products were size separated on a $1.5 \%$ agarose gel containing ethidium bromide and then exposed to ultraviolet light for photography.

Quantitative mRNA analysis was carried out for RXR$\alpha$, RXR- $\beta$, RXR- $\gamma 1$, RXR- $\gamma 2$, and TSH- $\beta$ using the ABI PRISM 7700 system (Perkin-Elmer Applied Biosystems, Foster City, California, USA). Primers and probes (containing fluorochrome and quencher) were generated against each specific RNA using the Primer Express program (Perkin-Elmer Applied Biosystems). (Primer and probe sequences are available upon request.) Primer and probe concentrations were optimized against total RNA containing all RXR isoforms (TtT-97 RNA; ref. 4) or a specific riboprobe for mouse TSH- $\beta$. TtT-97 total RNA and the TSH- $\beta$ riboprobe were subsequently used to generate quantitative standard curves for sample analysis. Standard curves were linear between $0.1 \mathrm{ng}$ and $200 \mathrm{ng}$ of total RNA for RXR- $\alpha(r=0.997)$, RXR- $\beta(r=0.993)$, RXR- $\gamma 1(r=0.992)$, and RXR- $\gamma 2(r=0.994)$. The standard curve for TSH- $\beta$ was linear between $0.1 \mathrm{fg}$ and $10,000 \mathrm{fg}$ of input pure riboprobe $(r=0.996)$. Total RNA was extracted from single pituitaries using the RNeasy method (QIAGEN Inc., Valencia, California, USA). Amplification reactions were performed in MicroAmp optical tubes (Perkin-Elmer Applied Biosystems) in a 50$\mu \mathrm{L}$ volume containing $8 \%$ glycerol; $1 \times$ TaqMan buffer $\mathrm{A}$ $(500 \mathrm{mM} \mathrm{KCl}, 100 \mathrm{M}$ Tris- $\mathrm{HCl}$ at $\mathrm{pH}$ 8.3, and $600 \mathrm{nM}$ passive reference dye ROX); $300 \mu \mathrm{M}$ each of dATP, dGTP, and dCTP; $600 \mu \mathrm{M}$ dUTP; $5.5 \mathrm{mM} \mathrm{MgCl}_{2} ; 12.5 \mathrm{U}$ Moloney murine leukemia virus reverse transcriptase (Life Technologies Inc., Gaithersburg, Maryland, USA); $1.25 \mathrm{U}$ AmpliTaq Gold DNA polymerase (Perkin-Elmer Applied Biosystems); 20 U RNasin ribonuclease inhibitor (Promega Corp.); and input RNA. Samples were run in duplicate with a control lacking reverse transcriptase; the signal of this control was consistently less than $1 \%$ of the RT-PCR reaction. Input total RNA was first determined against an $18 \mathrm{~S}$ ribosomal RNA (rRNA) control (Perkin-Elmer Applied Biosystems) that correlated well with the RNA amount determined by optical density. Input total RNA was 300-700 ng for the RXR isoform measurements and $100 \mathrm{ng}$ for TSH- $\beta$ measurements. Individual target RNA concentrations were corrected for input RNA based on rRNA measurements. Reverse transcription was performed at $48^{\circ} \mathrm{C}$ for $30 \mathrm{~min}$ utes, followed by activation of AmpliTaq Gold ${ }^{\circledR}$ at $95^{\circ} \mathrm{C}$ for 10 minutes. Subsequently, 40 cycles of amplification were performed, at $95^{\circ} \mathrm{C}$ for 15 seconds and $60^{\circ} \mathrm{C}$ for 1 minute. The detection threshold was set above the mean baseline fluorescence determined during the first 15 cycles; threshold cycle was determined when fluores- 

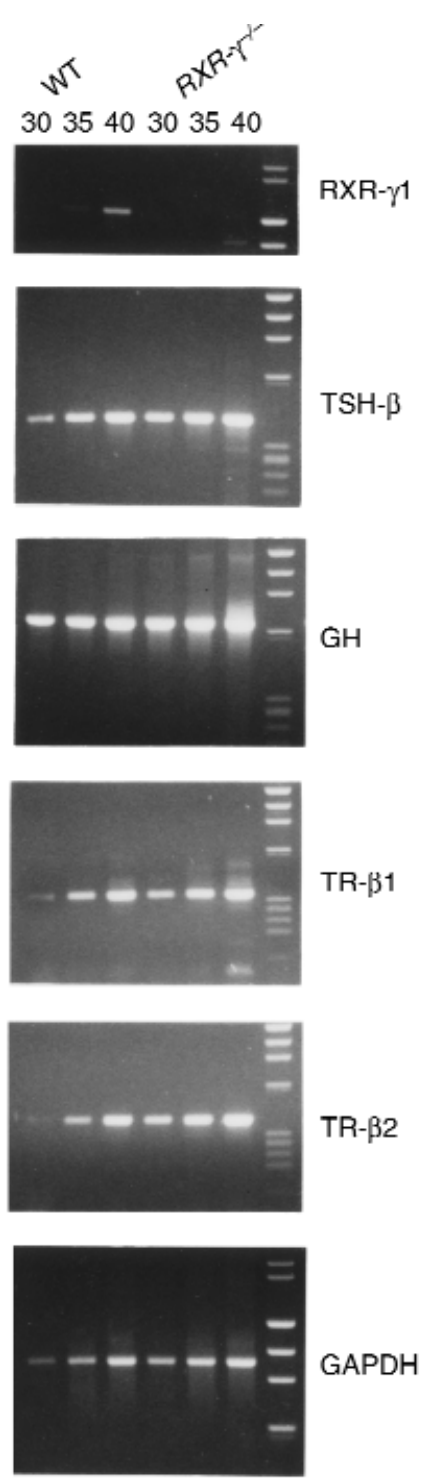

\section{Figure 1}

RT-PCR analysis of RNA from $R X R-\gamma^{\prime-}$ and WT mouse pituitaries. One microgram of total RNA was subjected to reverse transcription with random hexamers, and then to PCR with specific oligonucleotides for mouse RXR- $\gamma 1$ (mRXR- $\gamma 1$ ), mTSH- $\beta, m G H, m T R-\beta 1, m T R-\beta 2$, and $\mathrm{mGAPDH}$ as an RNA loading control. Product samples were removed at 30,35 , and 40 cycles and were analyzed on an agarose gel. The appropriately sized fragments were identified, and semiquantitative expression was compared between WT and $R X R-\gamma^{-1}$ mice.

cence intensity first increased above detection threshold. Sample values were generated from the standard curve. Serum assays. Serum was measured for T4 and T3 levels by standard radioimmunoassay. A mouse serum TSH assay was developed in our laboratory. The TSH assay was first validated with purified rat TSH by incubating $0.1-3.2 \mathrm{ng} /$ tube of rat TSH with a polyclonal rabbit antiserum raised against mouse TSH at a 1:5,000 dilution for 24 hours at $4^{\circ} \mathrm{C}$. Rat TSH labeled with ${ }^{125} \mathrm{I}$ (11) was added $(15,000-20,000 \mathrm{cpm}[0.05 \mathrm{ng}])$, and the mixture was incubated for 72 hours at $4{ }^{\circ} \mathrm{C}$. Goat anti-rabbit sec- ondary $\mathrm{Ab}$ (generated at our institution) was added, and the mixture was incubated for 3 hours at $4{ }^{\circ} \mathrm{C}$, followed by precipitation with $5 \%$ polyethylene glycol. The supernatant was removed, and pellets were counted for 5 minutes. To generate a mouse TSH standard curve, hypothyroid mouse serum from mice with TtT-97 thyrotrope tumors (with very high levels of serum TSH; ref. 12) was diluted at 1:50,000 and measured against the absolute rat standard to assign a "rat equivalent" value. Doubling dilutions of the hypothyroid mouse serum were made to generate a mouse TSH standard curve.

Immunobistochemistry. Paraffin-embedded pituitary sections were immunostained with polyclonal antisera against rat TSH- $\beta$ (AFP 1274789, 1:1,000; National Hormone and Pituitary Program, National Institute of Diabetes and Digestive and Kidney Diseases). A biotinylated secondary $\mathrm{Ab}$ was used in conjunction with avidin and peroxidase. Sections were counterstained with Gill's triple-strength hematoxylin.

Indirect whole-animal calorimetry. Energy expenditure was calculated from measurements in an indirect calorimeter. The indirect calorimetry system consists of cages, pumps, flow controllers, valves, and analyzers, and is calibrated with $\mathrm{O}_{2}(1 \%)$ and $\mathrm{CO}_{2}(0.8 \%)$ primary gas standards (Air Liquide, Houston, Texas, USA). The system is computer controlled and is designed to sequentially measure the $\mathrm{O}_{2}$ and $\mathrm{CO}_{2}$ concentrations in four separate cages on a continual basis. The system operates as follows: Air taken from a constant air source is pulled through four metabolic chambers (Metabowl; Jencons Scientific Ltd., Bridgeville, Pennsylvania, USA), a blank cage, and a reference line connected to separate but identical air-sampling pathways. Mice are placed in four metabolic chambers. The blank cage is used as a reference cage to monitor ambient $\mathrm{O}_{2}$ and $\mathrm{CO}_{2}$ concentrations periodically. The condensation in the air exiting the chambers is removed with electronic sample coolers (Universal Analyzers Inc., Carson City, Nevada, USA) and then pushed through mass flow controllers (Hastings Raydist; Teledyne Electronic Technologies, Hampton, Virginia, USA) that maintain constant air flow (0.75 $\mathrm{L} / \mathrm{min}$ ). The air then travels to a manifold with five valves that the computer at predefined intervals closes and opens, thereby shunting air from a cage through the $\mathrm{O}_{2}$ and $\mathrm{CO}_{2}$ analyzers (Oxymat/Ultramat 6; Siemens Energy \& Automation Inc., Roswell, Georgia, USA). The analyzers compare the $\mathrm{O}_{2}$ and $\mathrm{CO}_{2}$ levels in the cage air stream with those in a reference line. The differential $\mathrm{O}_{2}$ and $\mathrm{CO}_{2}$ concentrations, flow rate, respiratory quotient, and metabolic rate (calculated using the Weir equation) are calculated and stored in a computer configured with data-acquisition hardware (Analogic Corp., Wakefield, Massachusetts, USA) and software (LABTECH, Wilmington, Massachusetts, USA). The metabolic rate for each mouse is an average of measurements over three continuous days $(\mathrm{kcal} / \mathrm{d} / \mathrm{g})$.

Statistics. Statistical analyses comparing $R X R-\gamma^{\prime-}$ and wild-type (WT) mice were performed with the Student's $t$ test, except for the growth rates that were 


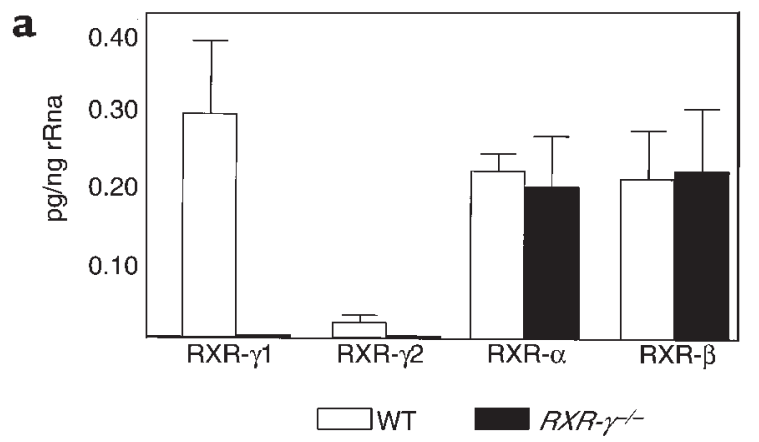

b

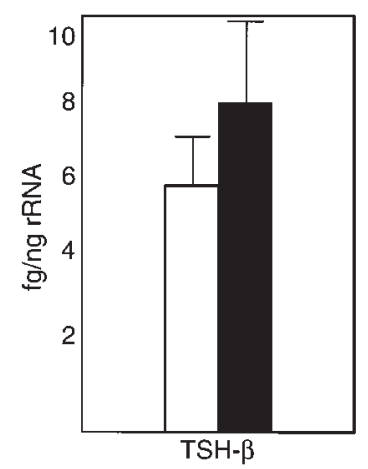

Figure 2

Quantitative RT-PCR analysis of RNA from $R X R-\gamma^{-/}$and WT mouse pituitaries. Total RNA was extracted from individual mouse pituitaries and then subjected to quantitative RT-PCR analysis as described in Methods. Results are from at least four separate pituitary samples. Error bars correspond to SEM. (a) mRNA levels of RXR isotypes in pg/ng rRNA from WT (open bars) and $R X R-\gamma^{-1}$ (filled bars) mice. (b) mRNA levels of TSH- $\beta$ subunit in $\mathrm{fg} / \mathrm{ng}$ rRNA from WT mice (open bars) and $R X R-\gamma^{-1-}$ mice (filled bars).

performed with two-way repeated measures ANOVA. A $P$ value of less than 0.05 was considered to be statistically significant.

\section{Results}

Phenotype of RXR- $\gamma$-deficient mice. Expected ratios of WT $(22 \%)$, heterozygotic (57\%), and homozygotic (21\%) mice were observed, as were expected ratios of males (48\%) and females (52\%) in 220 littermate mice. The average litter size was 5-8 pups in all groups. All mice appeared grossly normal, and gross locomotion was comparable in all groups. Krezel et al. (7) previously showed that $R X R-\gamma^{\prime-}$ mice lack expression of RXR- $\gamma$ protein in the pituitary. Using standard RTPCR, we examined pituitaries of mice 6-8 weeks old for RNA expression. $R X R-\gamma^{-1}$ mice lacked RXR- $\gamma$ mRNA (Figure 1), but levels of TR- $\beta 1$, TR- $\beta 2$, TSH- $\beta$, and growth hormone mRNA were comparable between WT and $R X R-\gamma^{\prime-}$ mice using this semi-quantitative analysis. A control lacking RNA was negative for all products at 40 cycles.

To determine the effect of lack of RXR- $\gamma$ on other RXR isoforms and TSH- $\beta$ mRNA, quantitative analysis was performed on pituitaries from individ- ual animals (with 3-6 $\mu$ g of total RNA obtained from each pituitary) using ABI PRISM ${ }^{\circledR} 7700$ quantitative real-time RT-PCR and fluorescent probes specific for each isoform. Neither RXR- $\gamma 1$ nor RXR$\gamma 2$ mRNA was detectable in pituitaries from the $R X R$ $\gamma^{/-}$mice using this sensitive technique (Figure 2a). Levels of RXR- $\alpha$ and RXR- $\beta$ mRNA were not significantly different between WT and $R X R-\gamma^{\prime-}$ mice, suggesting that there is no compensatory upregulation of these isoforms in mice lacking RXR- $\gamma$. Levels of TSH- $\beta$ mRNA were slightly higher in the $R X R-\gamma^{/-}$ mice, but these differences did not reach statistical significance $(P=0.14$; Figure $2 \mathrm{~b})$.

Baseline measurement of pituitary-thyroid function. Figure 3 shows baseline serum levels of T4, T3, and TSH in eight WT and eight $R X R-\gamma^{\prime-}$ littermate mice. Serum T4 levels were significantly higher in the $R X R-\gamma^{\prime}$ - mice (5.66 $\pm 0.15 \mu \mathrm{g} / \mathrm{dL})$ than in their WT littermates $(4.84 \pm 0.12$ $\mu \mathrm{g} / \mathrm{dL} ; P=0.001)$. Serum T3 levels were also higher in $R X R-\gamma^{\prime-}$ mice $(63.8 \pm 5.4 \mathrm{ng} / \mathrm{dL})$ than in WT controls $(56.1 \pm 3.1 \mathrm{ng} / \mathrm{dL})$, but these differences were not significant. Serum TSH levels were significantly higher in RXR$\gamma^{\prime-}$ mice $(5.98 \pm 0.40 \mathrm{ng} / \mathrm{mL})$ than in their WT littermates $(4.95 \pm 0.91 \mathrm{ng} / \mathrm{mL} ; P=0.01)$. This pattern of elevated serum thyroid hormone levels and elevated serum TSH is also seen in transgenic mice lacking the thyroid hormone receptor (TR- $\beta$ ), humans with thyroid hormone resistance, and vitamin A-deficient rats $(3,13)$.

Pituitary and thyroid histology. Because RXR- $\gamma$ has limited tissue expression that includes thyrotrope cells in the anterior pituitary and the thyroid gland, histologic analysis of these organs was performed; this revealed no basic differences between $R X R-\gamma^{\prime-}$ mice and WT mice (data not shown). To assess thyrotrope distribution and number within the anterior pituitary gland,

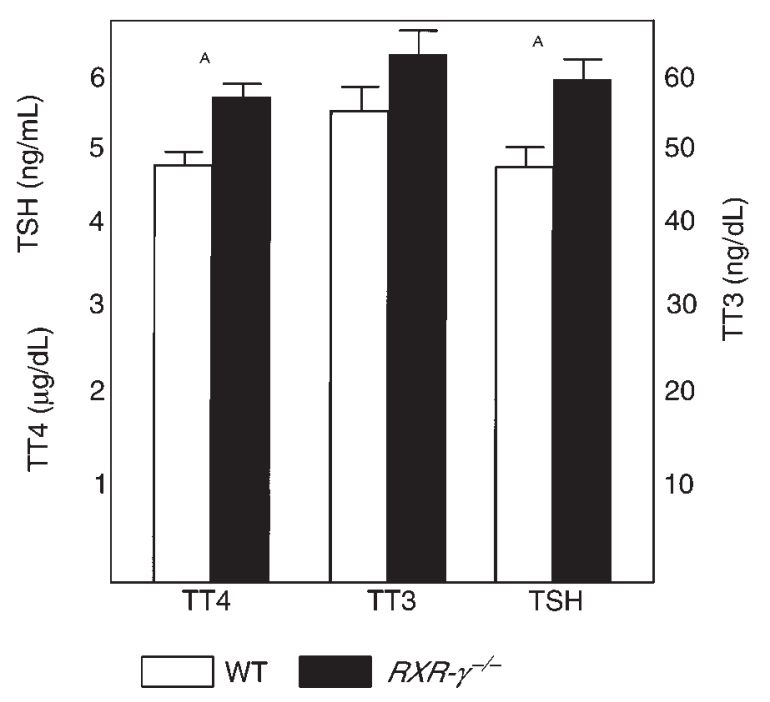

Figure 3

Serum TSH, T4, and T3 levels in littermate mice. Serum from eight WT mice (open bars) and eight $R X R-\gamma^{-1}$ mice (filled bars) are shown. TT4, total T4; TT3, total T3. Error bars indicate SEM. ${ }^{A} P=0.01$. 

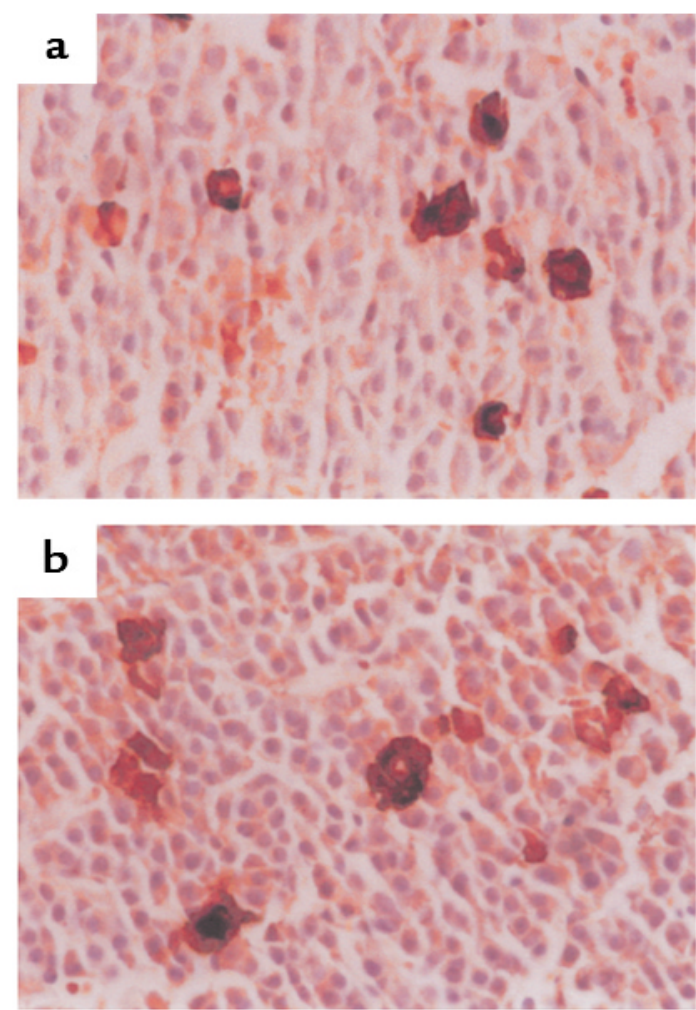

Figure 4

Immunohistochemistry of pituitaries from WT (a) and $R X R-\gamma^{-1}$ (b) mice. Brown cells indicate cytoplasmic staining of thyrotropes with antisera to rat $\mathrm{TSH}$ in representative sections.

immunohistochemistry was performed using a polyclonal antiserum against rat TSH. Figure 4 shows representative fields from pituitaries of $R X R-\gamma^{\prime-}$ and WT mice. The distribution of thyrotropes was similar in the two groups. The percentage of TSH-positive cells was also comparable in the $R X R-\gamma^{-1}$ mice $(3.3 \pm 0.2 \%)$ and WT mice $(3.7 \pm 0.9 \%)$, suggesting that normal thyrotrope development does not require RXR- $\gamma$.

Perturbations of the pituitary-thyroid axis. To further evaluate the pattern of mild thyroid hormone resistance seen in $R X R-\gamma^{-1}$ mice, littermates were treated with increasing amounts of $\mathrm{T} 3$ in the drinking water, and then serum TSH (Figure 5a) and T4 (Figure 5b) were measured. Serum TSH and T4 levels were higher in the $12 R X R-\gamma^{\prime-}$ mice than in the 18 WT littermates at each treatment dose of $\mathrm{T} 3$, except for the highest dose $(1.0 \mathrm{mg} / \mathrm{L})$. These data further support the hypothesis that $R X R-\gamma^{\prime-}$ mice have a central pattern of resistance to thyroid hormone.

To determine thyrotrope response to primary hypothyroidism, mice were rendered hypothyroid with $150 \mu \mathrm{Ci}{ }^{131}$ I, given intraperitoneally to ablate the thyroid gland. Four months after radioiodine treatment, serum was measured for TSH and T4, and pituitaries were collected for immunohistochemical analysis. Figure 6 shows that mice were rendered hypothyroid (determined by low serum T4 levels), and serum TSH was significantly elevated in both $R X R-\gamma^{-}$and WT mice compared with baseline (Figure 5a). $R X R-\gamma^{\prime-}$ mice again had higher serum TSH levels than did WT controls, despite higher levels of serum T4. Thyrotrope hyperplasia was observed in both $R X R-\gamma^{-}$and WT mice (data not shown), suggesting that thyrotropes in $R X R-\gamma^{\prime-}$ mice respond to severe hypothyroidism.

Metabolic rate. To explore the metabolic consequences of higher serum T4 and TSH levels in RXR- $\gamma^{\prime-}$ mice, littermate mice were studied in a whole-animal indirect calorimetry chamber in which measurements of oxygen consumption and carbon dioxide production were performed. To evaluate the impact of thyroid hormone on metabolic rate, four WT mice were studied at baseline (euthyroid) and after radioiodine treatment (hypothyroid, $\mathrm{T} 4<1 \mathrm{mg} / \mathrm{dL}$ ). Figure 7 a shows that euthyroid mice had a metabolic rate of $0.341 \pm 0.010 \mathrm{kcal} / \mathrm{d} / \mathrm{g}$ of body weight, and mice rendered hypothyroid had a 31\% lower metabolic rate $(0.235 \pm 0.015 \mathrm{kcal} / \mathrm{d} / \mathrm{g} ; P=0.001)$. Energy expenditure for the $R X R-\gamma^{\prime-}$ and WT mice is shown in Figure $7 \mathrm{~b}$. Six $R X R-\gamma^{\prime-}$ mice had a $37 \%$ higher metabolic rate $(0.434 \pm 0.033 \mathrm{kcal} / \mathrm{d} / \mathrm{g})$ than six WT littermates $(0.316 \pm$ $0.020 \mathrm{kcal} / \mathrm{d} / \mathrm{g} ; P=0.015)$, suggesting that the higher T4 levels in the $R X R-\gamma^{\prime-}$ mice may increase peripheral metabolism. Weights were not significantly different between the two groups (WT, $34.5 \pm 2.1 \mathrm{~g}$ vs. $R X R-\gamma^{\prime-}, 32.2 \pm 1.7 \mathrm{~g}$;
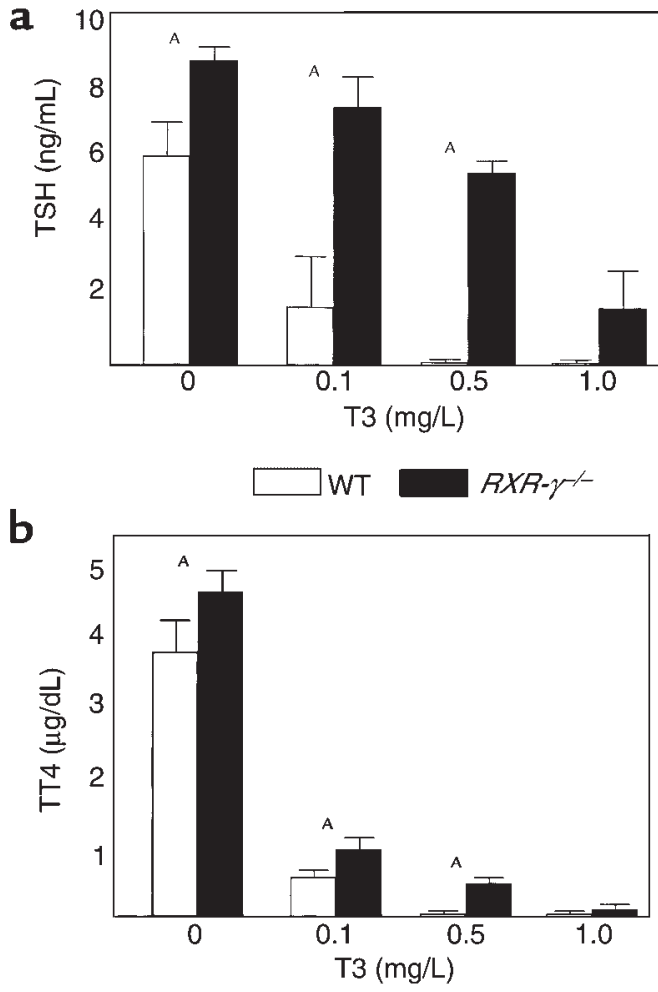

Figure 5

T3 suppression test in littermate mice. Serum from WT (open bars) and $R X R-\gamma^{-1}$ (filled bars) mice was collected after 10 days of treatment with different levels of $33(0 \mathrm{mg} / \mathrm{L}, 0.1 \mathrm{mg} / \mathrm{L}, 0.5 \mathrm{mg} / \mathrm{L}$, and 1.0 $\mathrm{mg} / \mathrm{L}$ ) in the drinking water. Serum TSH (a) and T4 (b) levels at each treatment dose are shown. ${ }^{A} P<0.05$. 


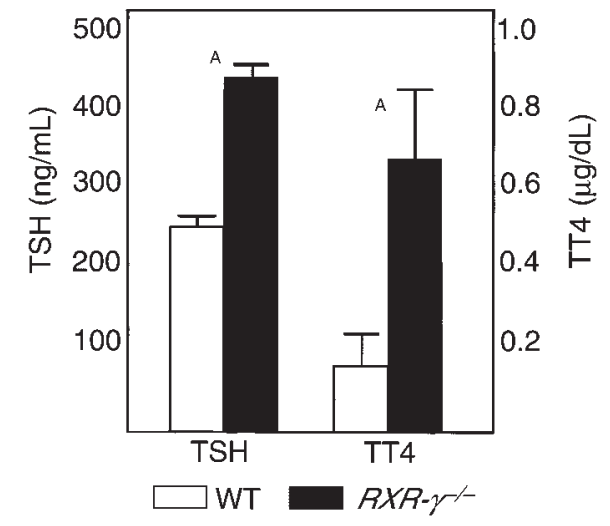

Figure 6

Serum TSH and T4 levels in WT and $R X R-\gamma^{\prime-}$ littermate mice after radioiodine-induced hypothyroidism. WT mice (open bars) and $R X R$ $\gamma^{/-}$mice (filled bars) were treated with $150 \mu \mathrm{Ci}$ of ${ }^{131}$ I, and serum was collected for TSH and T4 measurements after 4 months. ${ }^{A} P<0.05$.

$P=0.48)$. The growth rates of $20 \mathrm{WT}$ and $11 R X R-\gamma^{-}$mice were not significantly different $(P=0.093$; Figure 8$)$.

\section{Discussion}

In this study, we have demonstrated that mice lacking the thyrotrope-restricted RXR- $\gamma$ isotype have a phenotype consistent with thyroid hormone resistance and vitamin A deficiency $(3,13)$. Vitamin A, retinoids, and thyroid hormone can suppress serum TSH levels and decrease TSH- $\beta$ subunit gene promoter activity $(2-4,15)$. Retinoids appear to suppress TSH- $\beta$ promoter activity through the -200 to -149 region of the mouse and rat promoters $(5,16)$, which is different than the thyroid hormone response element located near the transcription start site $(15,17,18)$. These data suggest that the retinoid effect is unlikely to occur through an RXR-TR heterodimer as is seen with positively regulated genes. Inspection of the -200 to -149 region of the TSH- $\beta$ promoter reveals no consensus retinoid elements (DR1 or DR5), but alternate retinoid elements (DR0 and DR7) are present (19). The precise receptor or receptors mediating this response are currently unknown.

Recent reports have provided further insight into retinoid and potential receptor-mediated suppression of serum TSH and TSH- $\beta$ promoter activity. In collaboration with Sherman and colleagues (4), we have shown that the RXR-selective retinoids LG1069 and LG346 (Ligand Pharmaceuticals Inc., San Diego, California, USA) suppress serum TSH levels in humans and decrease TSH- $\beta$ promoter activity in vitro, suggesting a mechanism using a ligand-bound RXR. Because the RXR- $\gamma$ isotype has limited tissue distribution including the anterior pituitary and hypothalamus $(6,14)$, as well as thyrotropes within the anterior pituitary $(5,8)$, we hypothesized that the RXR- $\gamma$ isotype played a role in the regulation of the pituitary-thyroid axis.

The RXR isotypes may be redundant under certain circumstances, but gene deletion studies have revealed distinct roles for the three major isotypes. RXR- $\alpha$-deficient mice have severe cardiac and eye developmental defects and do not survive (20-22). RXR- $\beta$-deficient mice survive, but males appear to have abnormal spermatogenesis (23). In this report, we have shown that RXR- $\gamma$-deficient mice appear to survive and develop normally. Pituitary and thyroid histology are normal in these mice, and they reproduce normally. Specific analysis of the pituitary-thyroid axis reveals mild but significant elevations of serum TSH and T4 that do not suppress normally with the administration of T3. These data are consistent with a thyroid hormone resistance phenotype, but this is a more mild phenotype than that seen with lack of the TR- $\beta$ isoform (24). Using a different TSH assay, Barros and colleagues did not detect a significant elevation of TSH in these RXR- $\gamma$-deficient mice, although TSH levels were higher (24). Furthermore, they did not observe an additive effect on TSH and T4 elevation when the RXR- $\gamma$-deficient mice were crossed with TR- $\beta$-deficient mice, suggesting a dominant effect of TR- $\beta$ on regulation of the TSH-T4 axis. These data are consistent with the
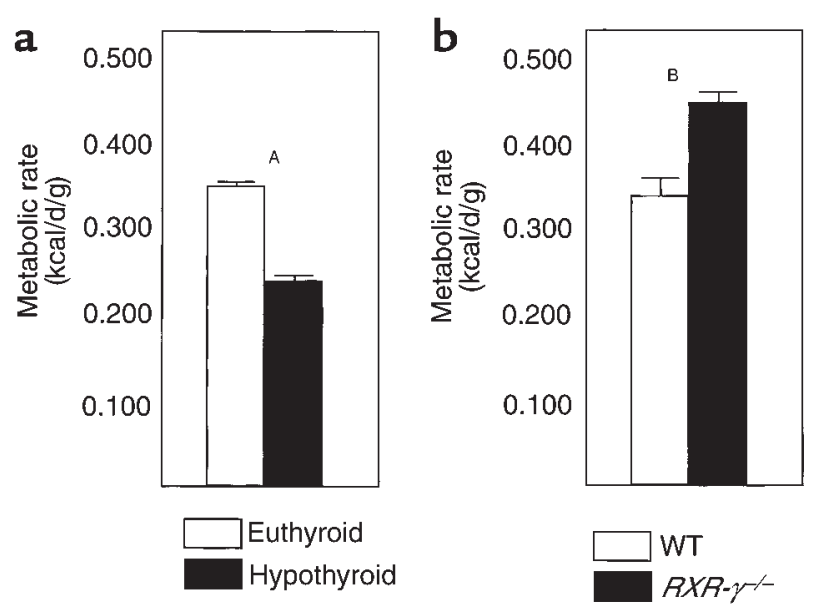

\section{Figure 7}

Metabolic rates in WT and $R \times R-\gamma^{-1}$ mice. (a) Metabolic rates $(\mathrm{kcal} / \mathrm{d} / \mathrm{g}$ ) in euthyroid (open bars) and hypothyroid (filled bars) WT mice. (b) Metabolic rates in WT (open bars) and $R X R-\gamma^{--}$(filled bars) littermate mice. ${ }^{A} P=0.001 ;{ }^{B} P=0.015$.

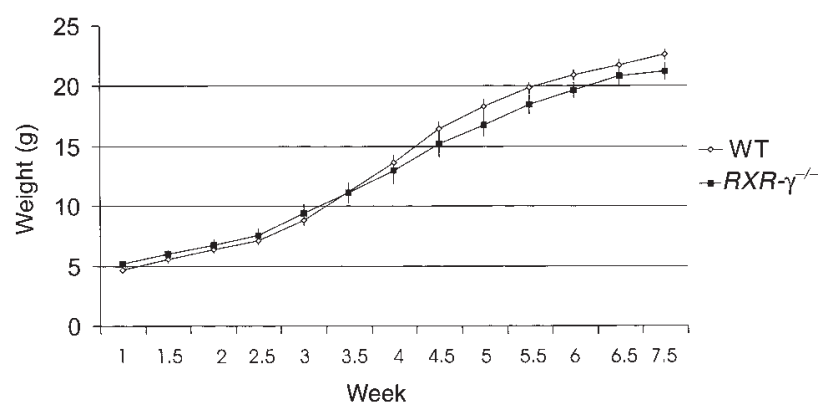

Figure 8

Growth rates of WT and $R X R-\gamma^{-/}$- littermate mice. Twenty WT mice (open diamonds) and $11 R X R-\gamma^{-/}$mice (filled squares) were weighed twice weekly between 1 week and 7.5 weeks of age. Error bars correspond to SEM. 
effects of thyroid hormone and vitamin A deficiency seen in other animal studies (25). In this study, mice were given increasing amounts of $\mathrm{T} 3$, which predictably decreased serum TSH and T4 levels in the WT animals. TSH and T4 levels also decreased in $R X R-\gamma^{\prime-}$ animals in response to T3 administration, but higher doses of T3 were required, suggesting a pattern of central thyroid hormone resistance. Levels of T4 decreased more than did TSH in the $R X R-\gamma^{-}$mice, suggesting a reduced effect of TSH on T4 production at the level of the thyroid. RXR- $\gamma$ is also expressed in the mouse (7) and human (B.R. Haugen, unpublished data) thyroid. RXR- $\gamma$ may play a separate role in the T4 response to TSH stimulation in the thyroid.

Because mice lacking RXR- $\gamma$ have mild elevations of $\mathrm{TSH}$ and T4, we examined the effects of these hormone changes on peripheral metabolism. Interestingly, mice lacking $R X R-\gamma$ had higher metabolic rates than their WT littermates did, suggesting that this gene plays a role in metabolism. One possibility is that the higher T4 levels affect peripheral organs (liver, heart, skeletal muscle) and increase metabolism, as is seen in patients with pituitary resistance to thyroid hormone (13). Another possibility is that these mice were simply eating more than their WT littermates were eating, which would cause increased metabolic rates. The weights of these animals, however, were not significantly different. Food intake was not directly measured in these experiments. RXR- $\gamma$ is highly expressed in skeletal muscle $(6,26)$, and this receptor isotype may play a direct role in skeletal muscle metabolism such as glucose or fat metabolism, which could account for the changes we have observed. A recent immunohistochemical and in situ hybridization analysis of all six RAR and RXR isotypes in the mouse central nervous system showed that RXR- $\gamma$ mRNA and protein have high levels of expression in the hypothalamus as well as in the anterior pituitary (14). Direct hypothalamic effects of RXR- $\gamma$ on food intake, metabolism, and TSH regulation by thyrotropin-releasing hormone must therefore also be considered. Future studies of body composition, food intake, heart rate (the RXR- $\gamma 2$ isoform is expressed in cardiac muscle) and manipulation of the pituitary-thyroid axis will be necessary to determine the role of RXR- $\gamma$ on metabolic rate.

In summary, we have demonstrated that mice lacking the RXR- $\gamma$ isotype have a phenotype consistent with thyroid hormone resistance and vitamin A deficiency. Furthermore, these mice appear to have an increased metabolic rate, which could be caused by the increased T4 levels or direct effects of RXR- $\gamma$ on organs such as skeletal or cardiac muscle. Because retinoids are being increasingly used as chemotherapeutic and chemopreventive agents, studies defining the precise role of these retinoids and receptors will provide important insight into the effects on the pituitary-thyroid axis and metabolism.

\section{Acknowledgments}

This work was supported by National Institutes of Health grants DK-02331 and DK-26356. Quantitative RT-PCR analysis was carried out in the Gene Expression Core Facil- ity of The University of Colorado Cancer Center. We thank Uma Pugazhenthi for her technical assistance in the quantitative RT-PCR analysis. We thank Arthur Gutierrez-Hartmann for review of this manuscript.

1. Simkins, S. 1947. Use of massive doses of vitamin A in the treatment of hyperthyroidism. J. Clin. Endocrinol. Metab. 7:574-585.

2. Shadu, D.P., and Brody, S. 1947. Excess vitamin A ingestion, thyroid size and energy metabolism. Am. J. Physiol. 149:400-404.

3. Morley, J.E., Damassa, D.A., Gordon, J., Pekary, A.E., and Hershman, J.M. 1978. Thyroid function and vitamin A deficiency. Life Sci. 22:1901-1906.

4. Sherman, S.I., et al. 1999. Central hypothyroidism associated with retinoid X receptor selective ligands. N. Engl. J. Med. 340:1075-1079.

5. Haugen, B.R., Brown, N.S., Wood, W.M., Gordon, D.F., and Ridgway, E.C. 1997. The thyrotrope-restricted isoform of the retinoid X receptor (gamma 1) mediates 9-cis retinoic acid suppression of thyrotropin beta promoter activity. Mol. Endocrinol. 11:481-489.

6. Mangelsdorf, D.J., et al. 1992. Characterization of the three RXR genes that mediate the action of 9-cis retinoic acid. Genes Dev. 6:329-344.

7. Krezel, W., et al. 1996. RXR gamma null mice are apparently normal and compound RXRa+/-, RXRb-/-, RXRg-/- mutant mice are viable. Proc. Natl. Acad. Sci. USA. 93:9010-9014.

8. Sugawara, A., Yen, P.M., Qi, Y., Lechan, R.M., and Chin, W.W. 1995. Isoform-specific retinoid-X receptor (RXR) antibodies detect differential expression of RXR proteins in the pituitary gland. Endocrinology. 136:1766-1774.

9. Sanno, N., et al. 1997. Immunohistochemical expression of retinoid X receptor isoforms in human pituitaries and pituitary adenomas. Neuroendocrinology. 65:299-306.

10. Gordon, D.F., et al. 1993. Analysis of Pit- 1 in regulating mouse TSHbeta promoter activity in thyrotropes. Mol. Cell. Endocrinol. 96:75-84.

11. Ross, D.S., Downing, M.F., Chin, W.W., Kieffer, J.D., and Ridgway, E.C. 1983. Divergent changes in murine pituitary concentration of free alpha and thyrotropin-beta subunits in hypothyroidism and after thyroxine administration. Endocrinology. 112:187-193.

12. Shupnik, M.A., and Ridgway, E.C. 1985. Triiodothyronine rapidly decreases transcription of the thyrotropin subunit genes in thyrotropic tumor explants. Endocrinology. 117:1940-1946.

13. Refetoff, S., DeGroot, L.J., Bernard, B., and DeWind, L.T. 1972. Studies of a sibship with apparent hereditary resistance to the intracellular action of thyroid hormone. Metabolism. 21:723-756.

14. Krezel, W., Kastner, P., and Chambon, P. 1999. Differential expression of retinoid receptors in the adult mouse central nervous system. Neuroscience. 89:1291-1300.

15. Wood, W.M., Kao, M.Y., Gordon, D.F., and Ridgway, E.C. 1989. Thyroid hormone regulates the mouse thyrotropin beta subunit gene promoter in transfected primary thyrotropes. J. Biol. Chem. 264:14840-14847.

16. Breen, J.J., Hickok, N.J., and Gurr, J.A. 1997. The rat TSH beta gene contains distinct response elements for regulation by retinoids and thyroid hormone. Mol. Cell. Endocrinol. 131:137-146.

17. Wondisford, F.E., et al. 1989. Thyroid hormone inhibition of human thyrotropin beta-subunit gene expression is mediated by a cis-acting element located in the first exon. J. Biol. Chem. 264:14601-14604.

18. Carr, F.E., Kaseem, L.L., and Wong, N.C. 1992. Thyroid hormone inhibits thyrotropin gene expression via a position-independent negative L-triiodothyroinine-responsive element. J. Biol. Chem. 267:18689-18694.

19. Castelein, H., Janssen, A., Declercq, P.E., and Baes, M. 1996. Sequence requirements for high affinity retinoid $\mathrm{X}$ receptor-alpha homodimer binding. Mol. Cell. Endocrinol. 119:11-20.

20. Sucov, H.M., et al. 1994. RXR alpha mutant mice establish a genetic basis for vitamin A signaling in heart morphogenesis. Genes Dev. 8:1007-1018.

21. Kastner, P., et al. 1994. Genetic analysis of RXR alpha developmental function: convergence of RXR and RAR signaling pathways in heart and eye morphogenesis. Cell. 78:987-1003.

22. Gruber, P.J., et al. 1996. RXR alpha deficiency confers genetic susceptibility for aortic sac, conotruncal, atrioventricular cushion, and ventricular muscle defects in mice. J. Clin. Invest. 98:1332-1343.

23. Kastner, P., et al. 1996. Abnormal spermatogenesis in RXR beta mutant mice. Genes Dev. 10:80-92.

24. Barros, A.C., et al. 1998. Absence of thyroid hormone receptor betaretinoid $X$ receptor interactions in auditory function and in the pituitary-thyroid axis. Neuroreport. 9:2933-2937.

25. Breen, J.J., Matsuura, T., Ross, A.C., and Gurr, J.A. 1995. Regulation of thyroid-stimulating hormone beta-subunit and growth hormone messenger ribonucleic acid levels in the rat: effect of vitamin A status. Endocrinology. 136:543-549.

26. Liu, Q., and Linney, E. 1993. The mouse retinoid-X receptor-gamma gene: genomic organization and evidence for functional forms. Mol. Endocrinol. 7:651-658. 